\title{
Cooperative Learning and Perception in Future Graduates of Business Administration and Management ${ }^{+}$
}

\author{
Raquel Gómez-López *, Patricia Martínez and Lidia Sanchez-Ruiz \\ Department of Business Administration, University of Cantabria, 39005 Santander, Spain; \\ martinezrp@unican.es (P.M.); sanchezrl@unican.es (L.S.-R.) \\ * Correspondence: gomezlr@unican.es; Tel.: +34-942-203-909 \\ + Presented at the 2nd Innovative and Creative Education and Teaching International Conference \\ (ICETIC2018), Badajoz, Spain, 20-22 June 2018.
}

Published: 29 October 2018

\begin{abstract}
The objective of this paper is to analyze the perception of future graduates in Business Administration and Management on the conceptualization, constitution and regulation of the work groups in the university classrooms. To achieve this objective, the Questionnaire for the Analysis of Cooperative Work in Higher Education (ACOES) will be used. The results show that the respondents consider that cooperative learning helps them to develop their social skills and is as an opportunity to get to know their peers. In addition, cooperative learning gives them the ability to reach agreements with different opinions and the ability to understand the ideas of other colleagues. Likewise, the main problem is the lack of coordination between the different subjects. Regarding the formation of the groups, the respondents prefer to form them by applying friendship criteria. Finally, the respondents consider that the groups should be permanents and formed by 4 or 5 members.
\end{abstract}

Keywords: cooperative learning; business administration and management; ACOES scale

\section{Introduction}

The adaptation to the EHEA has meant an important methodological revolution that presents a new attribution of meanings to the teaching and learning tasks [1], basically shifting the focus of attention from teachers to students. Following the research developed by [2] we can affirm that the ways of producing knowledge and learning are being modified, ceasing to be a simple application of transmitted knowledge and becoming the discovery and production of new knowledge. This new approach, focused on learning, makes it necessary to use methodologies that facilitate and reinforce the autonomous learning of the student, such as cooperative learning.

As the following authors affirm [3]: "Cooperative learning is the didactic use of small teams of students (between 3 and 5) to maximize the interaction between them in order to maximize the learning of all." Students must learn what instructors teach them and help their teammates learn as well. Indeed, one of the main objectives of working collaboratively at the University is to improve individual learning in contact with the group, understanding that collaborative learning, as indicated by [4] "is a process in which each individual learns more than that he/she would learn by himself/herself, fruit of the interaction of the members of the team" and provoking the exchange of knowledge and experiences.

Reference [5] argue that those who have had a learning context, in which the group activity is favored, attribute to themselves greater generic and reflective skills than those who come from conventional learning contexts. However, as noted by [6] we must bear in mind that a cooperative 
learning team is more than a group of students who do something together, one thing is to share the work and another is to cooperate with other people to make a common project.

The positive effects of cooperative work for student learning compared to other types of organization of classroom activities have been widely described in several studies over the last decades [7-9]. In addition, according to [10], a successful collaborative learning environment provides: 1 . Positive interdependence; 2 . Promotion of the interaction; 3 . Individual and group responsibility; 4 . Interpersonal and small group competencies; 5 . Group process.

In the light of the above, the objective of this paper is to analyze the perception of future graduates in Business Administration and Management on the conceptualization, constitution and regulation of the work groups in the university classrooms of the Faculty of Economic and Business Sciences at the University of Cantabria (Spain). To achieve this objective, the Questionnaire for the Analysis of Cooperative Work in Higher Education (ACOES) will be used.

\section{Questionnaire}

The goal of the ACOES Scale is to explore the extent to which university students value the importance of cooperative work in their learning process. This scale uses 5-point Likert scales to measure the items. The validated version is composed of 49 items categorized in seven dimensions: (1) Conception of group work; (2) Usefulness of group work for the learning process; (3) Planning of group work developed by teachers; (4) Criteria for organizing students' groups; (5) Rules for the groups; (6) Internal functioning of the groups; and (7) Efficiency of the group work [2].

\section{Results}

In the first place, the results referred to the students' general assessment about group work are presented. More than $70 \%$ of the respondents consider that cooperative learning helps them to develop their social skills and is as an opportunity to get to know their peers. Between $67 \%$ and $69 \%$ of the respondents showed that it is a very suitable instrument to better understand the content of the subjects and to share the total workload. In addition, it should be noted that less than $50 \%$ of students think that cooperative work as an optimal way to prepare for exams.

Regarding the usefulness of group work for their training, the results show that, more than $65 \%$ of the students think that it enhances their social interactions, being the ability to reach agreements with different opinions and the ability to understand the ideas of other colleagues the most valued ones. Likewise, $66.7 \%$ agree that group work is positive for their autonomous learning through the search for information and research. However, it should be noted that only $43.1 \%$ agree on the positive influence of group work for their future professional performance.

Secondly, the results corresponding to the students' evaluations about the organization of group work are presented. Regarding the planning of the group work by the teachers, as positive aspects, $62.6 \%$ think that the attendance to practical classes solves the doubts that arise during the development of the group work and $53.7 \%$ believe that the level of difficulty requested is appropriate to their training. However, it should be noted that for $44 \%$ of the respondents there is no adequate coordination between the different group works requested from different subjects. In the same way, $33.3 \%$ believe that the amount of group work requested does not adapt to the course load.

Regarding the criteria for forming groups, almost $80 \%$ of respondents believe that they should be stable throughout the semester or within the same subject; and $56.9 \%$ highlight its heterogeneous composition. Similarly, $42.3 \%$ think that the groups do not have to be formed by the faculty using academic criteria, but prefer to form them by applying friendship criteria (53.7\%). The need to appoint a group coordinator is a good idea for $40 \%$ of respondents and almost half of respondents believe that 4 participants is the most appropriate number of group members. Finally, within the organization of group work, the opinions on the groups' norms have been analyzed. More than $64 \%$ of the surveyed students believe that there must be rules that must be negotiated between teachers and students and, in addition, these rules must include, on the one hand, the consequences for participants that do not fulfil the commitments assumed $(68.3 \%)$ and, on the other hand, the obligation to attend meetings (63.4\%), and the roles of each member of the group (44.7\%). 
Third, the results corresponding to the internal functioning of the groups are presented. $75.6 \%$ of the surveyed students consult the basic documentation provided by the teacher and make consensual decisions to ensure the coherence of the overall work $(66.7 \%)$ by sharing their work $(62.6 \%)$, evaluating the work and making improvement proposals $(55.3 \%)$. In addition, group work requires carrying out searches of information in different sources $(58.5 \%)$. The main source of problems in the internal functioning of the groups is the lack of equitable participation of all the members of the group.

Between $74 \%$ and $84 \%$ of the students believe that the performance of the groups improves when teachers provide clear guidelines of the activities to be developed and the evaluation criteria. Likewise, it is important that the works are appropriately valued in the global mark of the subject and that the teachers supervise the work in group and control the regular attendance to class in order to improve the performance (50-70\%). Between $35-40 \%$ of respondents disagreed with the self-evaluation and with evaluating the rest of the members of their group, they believe that the teacher is the suitable person to do this task $(40 \%)$.

\section{Conclusions}

From the results of the study several conclusions should be highlighted. First, cooperative learning helps the students to develop their social skills and is an opportunity to get to know their classmates. In this way, according to [11] these students will develop social skills in an easy way such as listening to others, recognizing the others' success, apologizing to peers when an error has been made, among others. This is in line with the opinion of $68.3 \%$ of the students surveyed for whom cooperative learning allows them to reach agreements with different opinions. The lack of coordination between the different subjects is one of the main problems identified by teachers who want to explore new methodological approaches and tools such as collaborative work [12].

Regarding the formation of the groups, the results show that a high percentage of the respondents prefer to form them by applying friendship criteria. However, the students want to have a diverse composition in terms of gender, age, and training. This is in contrast with the work carried out by [13] who offers the idea of making heterogeneous groups, but where the teacher is the designer of them. Almost $80 \%$ believe that groups must be stable over time and be formed by 4 or 5 participants. In this sense, [14] advise that the groups should remain stable for long enough period of time that allow them to succeed, and these authors add that sometimes it is counterproductive to dissolve the groups that are having problems to function effectively, since students are prevented from learning skills that they need to solve the problems. As regards the number of participants, it should be noted that there is no ideal number of students that guarantees a good group work, but it seems that there is a consensus in the literature that it is preferable that there are between 3 and 5 students, since it is important that the size is an odd number in order to facilitate the consensuses, agreements or negotiations between its members [14-16].

In addition, $55.3 \%$ of respondents believe that it is necessary to control the attendance by the teacher through the application of cooperative learning. This fact is in line with what is explained by [17] who maximizes the relevance of the individual responsibility of the student, but does not eliminate the teacher's performance in the guide role. Precisely, controlling attendance configures an increase in the individual and group responsibility of each student.

Finally, more than $60 \%$ of the respondents considered not necessary to incorporate the evaluation of each other within the group or to perform a self-assessment of each student to the overall evaluation of the group. According to [18] the incorporation of the self-assessment on the achievement in the cooperative learning groups is determinant, so the proposed time for the students to participate in that evaluation is fundamental.

Author Contributions: R.G.-L., P.M., and L.S.-R. contributed to the design and implementation of the research, to the analysis of the results and to the writing of the manuscript.

Conflicts of Interest: The authors declare no conflict of interest. 


\section{References}

1. González Sanmamed, M.; Raposo Rivas, M. Necesidades formativas del profesorado universitario en el contexto de la convergencia europea. Rev. Investig. Educ. 2008, 26, 285.

2. Cabrera, M.D.; López, I.G.; Serrano, R.M. Validación del cuestionario de evaluación ACOES. Análisis del trabajo cooperativo en educación superior. Rev. Investig. Educ. 2012, 30, 87-109.

3. Johnson, D.W.; Johnson, R.T.; Holubec, E.J. El Aprendizaje Cooperativo en el Aula; Paidós: Buenos Aires, Argentina, 1999.

4. Guitert, M.; Guerrero, A.; Romeu, T.; Padros, A. ICT Competences for Net Generation Students. In Proceedings of the IEEE International Conference on Advanced Learning Technologies ICALT, Santander, Spain, 1-5 July 2008.

5. Gil Flores, J.; García Jiménez, E.; Santos López, C. Miradas retrospectivas de los egresados sobre la educación superior. Rev. Investig. Educ. 2009, 27, 371-393.

6. P Pujolás, 2007. Available online: http://www.unex.es/unex/servicios/sofd/archivos/ficheros/formacion/ Aprendizaje_Cooperativo.pps (accessed on 25 October 2018).

7. Sharan, S. Cooperative learning in small groups: Recent methods and effects on achievement, attitudes, and ethnic relations. Rev. Educ. Res. 1980, 50, 241-271.

8. Bossert, R. Chapter 6: Cooperative activities in the classroom. Rev. Res. Educ. 1988, 15, 225-250.

9. Qin, Z.; Johnson, D.W.; Johnson, R.T. Cooperative versus competitive efforts and problem solving. Rev. Educ. Res. 1995, 65, 129.

10. Johnson, D.; Johnson, R. Cooperative Learning. 2000. Available online: www.clcrc.com/pages/cl.html (accessed on).

11. Piaget, J.; Kohlberg, L. (1995) En El aprendizaje cooperativo y las competencias básicas. Rev. Digit. Prof. Enseñ. 2009, 5, 1.

12. García-Valcárcel, A.; Hernández, A.; Recamán, A. La metodología del aprendizaje colaborativo a través de las TIC: Una aproximación a las opiniones de profesores y alumnos. Rev. Complut. Educ. 2012, 23, 161.

13. Pujolás, P. El Aprendizaje Cooperativo; Graó: Barcelona, Spain, 2008.

14. Johnson, D.; Johnson, R.; Holubec, E. Circles of Learning: Cooperation in the Classroom; Interaction Book Company: Edina, MN, USA, 1986.

15. Rué, J. El aula: Un espacio para la cooperación. In Cooperar en la Escuela: La Responsabilidad de Educar para la Democracia; Mir, C., Ed.; Graó: Barcelona, Spain, 1998; pp. 17-51.

16. Escribano, A. Aprendizaje cooperativo y autónomo en la enseñanza universitaria. Enseñanza 1995, 13, 89.

17. Kagan, S.; High, J. Kagan Structures for English Language Learners; Kagan Publishing, Kagan Online Magazine: San Clemente, CA, USA, 2002.

18. Velázquez, C. Comprendiendo y aplicando el aprendizaje cooperativo en educación física. Rev. Esp. Educ. Fís. Deport. 2013, 40, 11.

(C) 2018 by the authors. Licensee MDPI, Basel, Switzerland. This article is an open access article distributed under the terms and conditions of the Creative Commons Attribution (CC BY) license (http://creativecommons.org/licenses/by/4.0/). 